IJORER : International Journal of Recent Educational Research Homepage : https://journal.ia-education.com/index.php/ijorer Email : ijorer@ia-education.com
p-ISSN : 2721-852X ; e-ISSN : 2721-7965 IJORER, Vol. 2, No. 2, March 2021: 138-146 (C) 2021 IJORER :

International Journal of Recent Educational Research

\title{
The Effectiveness of Information Services Using Problem Based Learning Approach to Reduce Academic Procrastination of Counseling Students
}

\author{
Anna Ayu Herawati ${ }^{*}$, Arsyadani Mishbahuddin², Mellyta Uliyandari ${ }^{3}$, Adif Jawadi Saputra ${ }^{4}$ \\ 1,2,3 Universitas Bengkulu, Bengkulu, Indonesia \\ 4 UIN Sumatera Utara, Medan, Indonesia
}

\begin{tabular}{|c|c|}
\hline (A) Check for updates open access cc) (i) (2) & DOI : https://doi.org/10.46245/ijorer.v2i2.79 \\
\hline Sections Info & ABSTRACT \\
\hline Article history: & This research is motivated by the very fact that there are still students who \\
\hline Submitted: December 28, 2020 & procrastinate, especially academic assignments, during this case, called the \\
\hline Final Revised: January 26, 2021 & wife of student academic procrastination. Efforts made in reducing the extent \\
\hline Accepted: March 21, 2021 & of student academic procrastination are information services employing a \\
\hline Published Online: March 31, 2021 & problem-based learning model. This research aims to look at the \\
\hline Keywords: & effectiveness of data services using problem-based learning models to scale \\
\hline ic procrastination & back student academic procrastination. This research uses quantitative \\
\hline tion services & methods. the sort of this research is Quasi Experiment with One Group \\
\hline Problem based learning & Pretest-Posttest Design. the themes of this research were counseling students \\
\hline 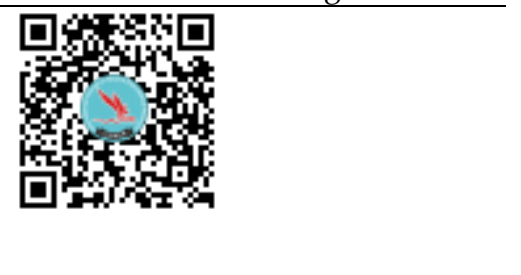 & $\begin{array}{l}\text { at the University of Bengkulu. The research instrument used was a Likert } \\
\text { scale model. The results showed that information services using effective } \\
\text { problem-based learning models to scale back student academic } \\
\text { procrastination. The implication of the results of this study is that it are often } \\
\text { used as input in creating guidance and counseling service programs, } \\
\text { especially in information services using problem-based learning models to } \\
\text { scale back student academic procrastination. }\end{array}$ \\
\hline
\end{tabular}

\section{INTRODUCTION}

Higher education is one of the formal educational institutions for students to be able to develop themselves and obtain maximum education and skills. Students as learners in higher education are required not only to have technical skills (Taufiq, 2018). The definition of scholars within the Big Indonesian Dictionary is students who study at education (Depdiknas, 2012). Students have a crucial role in realizing the ideals of national development, meanwhile tertiary institutions are educational institutions that are formally entrusted with the duties and responsibilities of preparing students consistent with the goals of upper education (Wulan \& Abdulah, 2014). They are required to have a certain strength and frame of mind as well as a mental attitude and personality, which is called a scientific or intellectual personality. It is through this type of personality that college graduates have broad insights, in contrast to those who have not received higher education. Students with a higher capacity are expected to be able to understand concepts, be able to map problems, and choose the best solution of the problems they are experiencing. Education in the current global era does not only require mastery and understanding of material but still requires students to have cognitive and social abilities to solve existing problems (Haryanti, 2017). According to Damri et al. (2017) stated that the position of students who are seen as academics in tertiary institutions will always deal directly with assignments that are both academic and non-academic. Completing these assignments often causes various problems in students, depending on the characteristics possessed by students. Student characteristics are different and have various obstacles that arise in students in carrying 
The Effectiveness of Information Services Using Problem Based Learning Approach to Reduce Academic Procrastination of Counseling Students

out their academic activities. One of the problems that often arise among students is academic procrastination. Veronica (2012) defines procrastination as a delay that is carried out deliberately and repeatedly, by doing other activities that are not needed in carrying out tasks.

According to Wulan \& Abdullah (2014), there are many types of delays made by students, one of which is the data about the delay in writing theses as many as 14 psychology students. According to the Big Indonesian Dictionary (2012) delays are defined as postponing activities which can be seen by stopping activities or carrying out activities at a later time. The results of You's research (2015) show that at a Korean University, out of 569 students studied, 56.39\% carried out academic procrastination. Academic procrastination that is carried out leads to fun things such as watching movies for hours, online games, this activity is more fun than doing academic assignments, so there is a delay in collecting lecture assignments. Furthermore, in Janssen's (2015) study, 57.1\% of 133 students are in the high academic procrastination category. Furthermore, based on the results of research by Savira \& Suharsono (2013) on 48 students of class XI of the acceleration program at Senior High School Malang, it is known that $52.1 \%$ of students are in the high academic procrastination category. The results of further research conducted by Sari (2013) on 120 students of class XII at Senior High School of Muhammadiyah 2 Yogyakarta showed that $66.7 \%$ of students were in the moderate academic procrastination category. Furthermore, Ulum (2016) found that $79.4 \%$ of the 68 class XI IPA students at Senior High School 1 Ngamprah, West Bandung Regency were in the moderate academic procrastination category.

For the intensity of student academic procrastination to decrease, it becomes a challenge for the higher education institution, especially BK lecturers to assist students, so that students can plan and determine the right steps to complete all kinds of tasks and academic demands properly. One of the guidance and counseling services is an information service. Through the use of the learning model, it is expected to be able to provide different nuance to the learning process experienced by students. The learning model is a whole series of teaching material presentation that includes all aspects before, during, and after learning by the teacher and all related facilities that are used directly or indirectly in the learning process (Uliyandari \& Elly, 2020).

One example of an approach model which will be provided in information services is that the problem-based learning model. Problem Based Learning (PBL) learning model links the important world with the issues to be discussed. the utilization of this learning model will hone students' critical thinking skills to realize knowledge from the topic matter (Daryanto \& Tarno, 2015). PBL is an innovative learning model that gives active learning conditions for college students (Nisa, 2015; Safaruddin, et al., 2020). Yamin (2012) states that "problem-based learning is one of the innovative learning models that provide active learning conditions for students in real-world conditions". The real-world situation referred to here is student academic procrastination.

Wynn et al. (2014) where the characteristics of student cognitive development are suitable if given a learning model that stimulates a thinking model with problems, cases, and problem-solving discussions as contained in the PBL model. According to Utomo, Wahyuni \& Hariyadi (2014). PBL may be a learning model that needs mental activity of scholars to know a learning concept through situations and problems 
The Effectiveness of Information Services Using Problem Based Learning Approach to Reduce Academic Procrastination of Counseling Students

presented at the start of learning with the aim of coaching students to unravel problems using the approach and solution to problem.

The Problem Based Learning Model may be a learning model based on a specific issue (Bakhri \& Supriadi, 2017). The advantages of the PBL model according to Shoimin (2016) include: 1) students are trained to have the ability to solve problems in a real state, 2) can build their own knowledge through learning activities, 3) learning focuses on problems so that material that has nothing to do with it does not need to be learned by students. This reduces the burden on students by memorizing or storing information, 4) scientific activity occurs in students through group work, 5) students are accustomed to using knowledge sources, both from libraries, the internet, interviews, and observations, 6) students can assess their own learning progress, 7) students have the ability to carry out scientific communication in discussions or presentations of their work, and 8) individual learners' learning difficulties can be overcome through group work in the form of peer teaching. PBL learning steps are the delivery of basic concepts, problem definitions, independent learning, knowledge exchange, and assessment in which there are stages of the approach to learning (Sani, 2014).

Based on the explanation above in the lecture process, lecturers need to design a learning strategy that is seen as being able to reduce student of academic procrastination by involving the ability to solve problems that have been owned by guidance and counseling students. For this reason, this study was conducted with the aim of obtaining conclusions about the effectiveness of information services using a problem-based learning model to reduce academic procrastination in guidance and counseling students. The use of problem-based learning models provided through information services is expected to be able to educate students to be able to actively build their own knowledge of academic goals, be able to think critically, and be able to solve real problems that exist in everyday life and produce real knowledge.

\section{Research Aim}

To Describe of the level of student procrastination before being given information service treatment without using a problem-based learning's model, describe the level of student procrastination after being a given information service treatment without using a problem-based learning models, and the difference in student procrastination before and after being given information service treatment without using a problem-based learning model.

\section{RESEARCH METHOD \\ General Background}

The method are used in this researchs is a quasi-experimental design with One Group Pretest-Posttest Design. Experimental research is research that is carried out deliberately by researchers by providing certain treatments / treatments to research subjects in order to generate an event / situation that will be investigated how the consequences are (Jaedun, 2011). The research is a models quantitative study using experimental research methods. Experimental research aims to determine the effect of manipulation on observed individual behavior. The research group was given treatment with information services using a problem-based learning model, only completing the initial test (pretest) and the final test (posttest). The independent 
The Effectiveness of Information Services Using Problem Based Learning Approach to Reduce Academic Procrastination of Counseling Students

variable of this study is information services using a problem-based learning model. Meanwhile, the dependent variable is student academic procrastination.

\section{Sample / Participants / Group}

The technique of taking the subject used in this research is the non-random sampling technique, namely the purposive sampling method (purposive sampling). According to Sugiyono (2016) states that purposive sampling is a technique of sampling data sources with certain considerations. The samples of this research are 39 students of guidance and counseling program semester 1 .

\section{Instrument and Procedures}

The instrument used in this research used a non-test method in the form of an academic procrastination questionaire. The indicators used in the questionnaire to determine the level of student procrastination are: writing assignments, study assignments to face exams, reading assignments, administrative tasks, and student attendance assignments.

\section{Validity Test Results}

The resultss of testing the validity of the measuring instrument (scale) of academic procrastination of the Guidance and Counseling students at the University of Bengkulu with a validity coefficient of 0.3 , while the number of valid and invalid items can we see in the following Table 1.

Table 1. Results of the academic procrastination scale validity test.

\begin{tabular}{llll}
\hline \multirow{2}{*}{\multicolumn{1}{c}{ Aspect }} & \multicolumn{1}{c}{ Items } & \multirow{2}{*}{ total } \\
\cline { 2 - 3 } & \multicolumn{1}{c}{ Valid } & \multicolumn{1}{c}{ Not valid } \\
\hline Writing assignments & $1,2,4,5,6,8,9,11$ & $3,7,10$ & 11 \\
study assignments facing exams & $12,13,14,16,18,20$ & $15,17,19$ & 9 \\
Reading assignments & $21,22,23,24,25,26,27$ & - & 7 \\
Administrative duties & $28,29,31,32,34,35$ & 30,33 & 8 \\
student attendance assignments & $36,37,38,40$ & 39 & 5 \\
total & 31 & 9 & 40 \\
\hline
\end{tabular}

\section{Reliability Test Results}

In this research, to test the reliabilitty of the instrument, the Cronbach Alpha's formula was used, while the reliability test results can be seen in the following Table 2

Table 2. Reliability test results academic procrastination scale.

\begin{tabular}{cc}
\hline \multicolumn{2}{c}{ Reliability Statistics } \\
\hline Cronbach's Alpha & N of Items \\
, 811 & 31 \\
\hline
\end{tabular}

Based on the results of the when viewed from the results reliability test in Table 2, the results are 0.811 . this indicates a value of more than 0.6 so that it meets the reliable criteria.

\section{Procedures}

This research procedure uses experimental research methods with one group pre-test and post-test design. Purposive sampling technique was used in the sampling of this 
The Effectiveness of Information Services Using Problem Based Learning Approach to Reduce Academic Procrastination of Counseling Students

research. This research begins with the researcher distributing a pre-test questionnaire, then from the results of pre-test data processing, treatment will be given in the form of information services using a problem-based learning approach, then after being given the treatment, a post-test questionnaire will be given again with a statement which is the same as the pre-test.

\section{Data Analysis}

To obtain results, the data analysis technique was carried out by looking at the characteristics of the data. Research data to reduce student procrastination variables have the following characteristics: (1) in pairs (pretest-posttest), (2) small samples (research subjects), and (3) using experimental / treatment research, and test using SPSS 21 software for windows. The test is carried out at a significant level of $5 \%$, meaning that to determine the $t$-table statistical value, the significant level is used $a=0.05$ with degrees of freedom $d k=(n-k-1)$, with the testing criteria accepted Ho If $t<t$ table, and accepted Ha if $t$ count $\geq t$ table.

Reducing the level of student academic procrastination can be seen by calculating the difference between the pretest and posttest scores to determine the decrease in the level of students academic procrastination before-after being provided with information services using the Problem-Based-Learning (PBL) learning models. The data description of the students procrastination level was analyzed using the percentage formula. According to Kamelta (2013) percentage can be calculated with the following formula:

Where :

$$
\mathrm{P}=\mathrm{f} / \mathrm{N} \times 100 \%
$$

$$
\begin{array}{ll}
\mathrm{P} & =\text { Percentage of answers } \\
\mathrm{f} & =\text { Frequency of respondents' answers } \\
\mathrm{N} & =\text { Total frequency }
\end{array}
$$

\section{RESULTS AND DISCUSSION}

The data obtained are the results of the pretest and posttest related to student procrastination. The following is presented the score of each student procrastination

\begin{tabular}{|c|c|c|c|c|c|c|c|}
\hline \multirow[t]{2}{*}{ Interval } & \multirow[t]{2}{*}{ Criteria } & \multicolumn{2}{|c|}{ Pretest } & \multicolumn{2}{|l|}{ Postest } & \multirow[t]{2}{*}{ T-Test } & \multirow{2}{*}{$\begin{array}{l}\text { Sig. (2- } \\
\text { tailed) }\end{array}$} \\
\hline & & Frequency & $\%$ & Frequency & $\%$ & & \\
\hline$\geq 100$ & Very high & 6 & 15,38 & 1 & 2,56 & & \\
\hline $92-99$ & high & 14 & 35,90 & 1 & 2,56 & & \\
\hline 82-91 & medium & 12 & 30,77 & 13 & 33,33 & & \\
\hline $64-81$ & low & 7 & 17,95 & 23 & 58,97 & & \\
\hline$\leq 63$ & Very low & 0 & 0 & 1 & 2,56 & & \\
\hline Total & & 39 & 100 & 39 & 100 & 25,327 & 0.000 \\
\hline
\end{tabular}
before and after being given treatment in Table 3.

Table 3. The results of the academic procrastination pretest and postest for class 1B students of the academic year 2019/2020

After being given the treatment there was a change where it can be seen from the posttest results that 1 student was with a very high category seen from the percentage $2.56 \%, 1$ person in the high category seen from the percentage of $2.56 \%$, the moderate 
The Effectiveness of Information Services Using Problem Based Learning Approach to Reduce Academic Procrastination of Counseling Students

category was 13 people with a percentage of $33.33 \%$, the low category was 23 people seen from the percentage of $58.97 \%$ and the very low category was 1 person seen from the percentage of $2.56 \%$. Based on the description of these data, it can be concluded that there are differences in the level of academic procrastination of students before and after being treated with information services using a problem-based learning model. Of the 39 students who received treatment, 38 students experienced changes, namely a decrease in the level of student academic procrastination. Individual abilities in carrying out academic tasks are often influenced by their beliefs, this is related to the belief that using a variety of learning models can at least reduce students delaying work (Muyana, 2018).

Based on the results of the study, it was found that there were differences in levels of academic procrastination of students before being given information services using a problem-based learning model and after being given information services using a problem-based learning model. Based on the implementation of information services using a problem-based learning model, currently, students are more active in participating in service activities, this can be seen from the seriousness of students participating in group discussions. Furthermore, students can solve problems from the questions that have been given, students can also convey the results of their group discussions well. Unlike the time before the problem-based learning model approach was carried out, the service activities did not form groups, researchers only provided ordinary information services so that students were less active in conveying the results of their understanding. The problems in the PBL approach become a stimulus for students in learning activities whereas learning itself is aimed at finding solutions to problems (Orozco \& Yangco,2016). This is in line with the research of Gunantara, Suarjana \& Riastini (2014) which shows that the Problem Based Learning (PBL) learning model can improve problem solving abilities in Mathematics subjects.

Based on the results of data analysis, it can be concluded that information services using a problem-based learning model are more effective in reducing student procrastination. The effectiveness of this can be seen from the overall number of analyzes carried out in which the score of the results of the student's procrastination level has decreased which is higher than before being provided with information services using a problem-based learning model approach. Thus the use of varied and innovative teaching methods in implementing information services is able to direct students to think more directed. This is supported by the results of Anugraheni's (2018) research that based on the results of the analysis, it turns out that the Problem Based Learning learning model is able to improve students' thinking abilities starting from the lowest $2.87 \%$ to the highest $33.56 \%$ with an average of $12.73 \%$.

\section{CONCLUSIONS}

Based on the research results obtained in general, Based on the explanation of the research results, it can be concluded that information services with a problem-based learning model are more effective in reducing student academic procrastination than information services without using a problem-based learning model. Specifically, the findings of this study are as follows: there is a description of student academic procrastination before participating in information services using a problem-based learning model, there is a description of student academic procrastination after 
participating in information services using a problem-based learning model, and there is a significant difference in student academic procrastination before and after participating in information services using a problem-based learning model. In the categorization of students' academic procrastination scores before being given the treatment it is in the high category, while the greater average increase occurs in students after being given treatment. Based on the explanation above, it can be concluded that information services that have been tested for their effectiveness in this study aim to invite students to be able to solve their own problems regarding the concept of academic procrastination, then be able to actualize and implement and make overall decisions about what students get. So that the problem based learning model can be recommended to be applied in the classroom to reduce the level of student procrastination. In-depth research on student academic procrastination for all indicators is highly recommended to obtain better results.

\section{REFERENCES}

Anugraheni, I. (2018). Meta analisis model pembelajaran problem based learning dalam meningkatkan keterampilan berpikir kritis di sekolah dasar. Polyglot: Jurnal Ilmiah, 14(1), 9-18.

Bakhri, Syaifulloh \& Supriadi. (2017). Peran problem-based learning (PBL) dalam upaya peningkatan higher order thinking skills (HOTS) siswa pada pembelajaran matematika. Seminar Matematika Dan Pendidikan Matematika UNY 2017.

Damri, D., Engkizar, E., \& Anwar, F. (2017). Hubungan self-efficacy dan prokrastinasi akademik mahasiswa dalam menyelesaikan tugas perkuliahan. JURNAL EDUKASI: Jurnal Bimbingan Konseling, 3(1), 74-95.

Daryanto \& Tarno. (2015). Pengelolaan budaya dan iklim sekolah. Yogyakarta: Penerbit Gava Media

Depdiknas. (2012). Kamus besar bahasa Indonesia. Jakarta. Penerbit: Gramedia Pustaka Utama.

Gunantara, G., Suarjana, I. M., \& Riastini, P. N. (2014). Penerapan model pembelajaran problem based learning untuk meningkatkan kemampuan pemecahan masalah matematika siswa kelas V. MIMBAR PGSD Undiksha, 2(1).

Haryanti, Y, D. (2017). Model problem based learning membangun kemampuan berpikir kritis siswa sekolah dasar. Jurnal Cakrawala Pendas, 3(2), 57-63. http://dx.doi.org/10.31949/jcp.v3i2.596

Yamin, M. (2012). Desain baru pembelajaran konstruktivistik. Jakarta: Referensi

Ilfiandra. (2012). Penanganan prokrastinasi akademik mahasiswa sekolah menengah atas: konsep dan aplikasi. Jurnal Psikologi Pendidikan dan Bimbingan, 39(4), (http://jurnalikipnegerisingaraja.ac.id, diakses Mei 2019).

You W.,J. 2015. Examining the effect of academic procrastination on achievement using LMS data in e-learning. Journal of Educational Technology and Society, 18(3), 64-74.

Yulianti, E., \& Indra Gunawan. (2019). Model pembelajaran problem based learning (pbl) : efeknya terhadap pemahaman konsep dan berfikir kritis. Indonesia Journal of Science and Mathematics Education, 2(3), 399-408. https:/ / doi.org/10.24042/ijsme.v2i3.4366

Jaedun, A. (2011). Metodologi penelitian eksperimen. Fakultas Teknik UNY, 12. 
The Effectiveness of Information Services Using Problem Based Learning Approach to Reduce Academic Procrastination of Counseling Students

Janssen, J. O. (2015). Academic procrastination: prevalence among high school and undergraduate student and relationship to academic achievement. (Doctoral dissertation), Retrieved from http://scholarworks.gsu.edu/epse_diss/103

Kamelta, E. (2013). Pemanfaatan internet oleh mahasiswa jurusan teknik sipil fakultas teknik universitas negeri padang. JurnalPendidikan, 1(2), 142-146.

Mariyanti, S. (2012). "Prokrastinasi (kebiasan menunda tugas/pekerjaan) ".http://www.esaunggul.ac.id/article/prokrastinasi-kebiasan-menundatugaspekerjaan/ diakses Mei 2019).

Muyana, S. (2018). Prokrastinasi akademik dikalangan mahasiswa program studi bimbingan dan konseling. Counsellia: Jurnal Bimbingan dan Konseling, 8(1), 45-52.

Nisa, A. K.(2015). Implementasi model pembelajaran problem based learninguntuk meningkatkan keaktifan dan hasil belajar siswa pada mata pelajaran pemrograman desktop kelas XI RPL smk ma'arif Wonosari. (Skripsi).Universitas Negeri Yogyakarta

Orozco, J. A., \& Yangco, R. T. (2016). Problem-based learning: Effects on critical and creative thinking skills in biology. Asian Journal of Biology Education, 9(3).

Prayitno. (2012). Seri panduan layanan dan kegiatan pendukung konseling. Padang: UNP Press.

Putri, R. D. (2016). Efektivitas layanan informasi dengan pendekatan contextual teaching and learning dalam meningkatkan arah perencanaan karier mahasiswa SMK. Tesis tidak diterbitkan. Padang: Prodi S2 BK FIP UNP.

Rusman. (2016). Model-model pembelajaran: Mengembangkan profesionalisme guru. Jakarta: Rajawali Pers.

Safaruddin, Degeng, I. N. S., Setyosari, P., \& Murtadho, N. (2020). The effect of PJBL with WBL media and cognitive style on students' understanding and scienceintegrated concept application. Jurnal Pendidikan IPA Indonesia, 9(3), 384-395. https://doi.org/10.15294/jpii.v9i3.24628.

Sani, R. A. (2014). Pembelajaran saintifik untuk implementasi kurikulum 2013.

Sari, D. N. (2013). Hubungan antara stres terhadap guru dengan prokrastinasi akademik pada siswa SMA Muhammadiyah 2 Yogyakarta. EMPATHY: Jurnal Fakultas Psikologi, 2(1). Diunduh dari http://www.jogjapress.com/index.php/EMPATHY/article/view/1525/863

Savira, F., \& Suharsono, Y. (2013). Self-regulated learning (SRL) dengan prokrastinasi akademik pada siswa akselerasi. Jurnal Ilmiah Psikologi Terapan, 1(1), 66-75.

Shoimin, A. (2016). Model pembelajaran inovatif dalam kurikulum 2013. Yogyakarta: ArRuzz Media.

Sugiyono. (2016). Metode penelitian kuantitatif, kualitatif dan REDD. Bandung: Alfabeta

Tatan, Z. M. (2012). Analisis Prokrastinasi Tugas Akhir atau Skripsi. Prosiding. ISBN : 978979-16353-8-7.

Taufiq, A. (2018). Paradigma baru pendidikan tinggi dan makna kuliah bagi mahasiswa. Jurnal Politik dan Sosial Kemasyarakatan, 10(2), 34-52.

Tohirin. (2015). Bimbingan dan konseling di sekolah dan madrasah (Berbasis Integrasi). Jakarta: Rajawali Pers.

Uliyandari, Mellyta \& Elly E. L. (2020). Penerapan model pembelajaran inkuiri dengan media alat peraga (gunung berapi) pada mata pelajaran IPA SDN 013 Bengkulu 
The Effectiveness of Information Services Using Problem Based Learning Approach to Reduce Academic Procrastination of Counseling Students

Utara. PENDIPA Journal of Science Education, 4(2), 74-78. https://doi.org/10.33369/pendipa.4.2.74-78

Ulum, M. I. (2016). Strategi self-regulated learning untuk menurunkan tingkat prokrastinasi akademik siswa. Psympathic: Jurnal Ilmiah Psikologi, 3(2), 153-170. http://dx.doi.org/10.15575/psy.v3

Utomo, T., Wahyuni, D., \& Hariyadi, S. (2014). Pengaruh model pembelajaran berbasis masalah (problem based learning) terhadap pemahaman konsep dan kemampuan berpikir kreatif siswa (siswa kelas viii semester gasal smpn 1 sumbermalang kabupaten Situbondo tahun ajaran 2012/2013). Jurnal Edukasi, 1(1), 5-9.

Veronica, S. (2012). "Hubungan antara self control dengan prokrastinasi akademik pada mahasiswaa program studi pendidikan sejarah UNP". Jurnal Humanus, X(1), 1-9.

Wynn Sr, C. T., Mosholder, R. S., \& Larsen, C. A. (2014). Measuring the effects of problembased learning on the development of postformal thinking skills and engagement of first-year learning community students. Learning Communities: Research \& Practice, 2(2), 4

Wulan, D.A.N., \& Abdullah, S.M. (2014). Prokrastinasi Akademik dalam Penyelesaian Skripsi. Jurnal Sosio-Humaniora, 5(1), 55-74.

Wulandari, B., \& Surjono, H. D. (2013) Pengaruh problem based learning terhadap hasil belajar ditinjau dari motivasi belajar PLC di SMK. Jurnal Pendidikan Vokasi, 3(2), 178191.

\footnotetext{
*Anna Ayu Herawati, S.Pd., M.Pd (Corresponding Author)

Guidance and counseling Study Program, Faculty of Education,

Universitas Bengkulu

WR Supratman St, Kandang Limun. Bengkulu, 38123, Indonesia

Email: annaayuherawati@unib.ac.id
}

\section{Arsyadani Mishbahuddin, M.Pd.I}

Guidance and counseling Study Program, Faculty of Education, Universitas Bengkulu

WR Supratman St, Kandang Limun. Bengkulu, 38123, Indonesia

Email: haidardani01@gmail.com

\section{Mellyta Uliyadari, M.Pd.Si}

Science Education Study Program, Universitas Bengkulu

WR Supratman St, Kandang Limun. Bengkulu, 38123, Indonesia

Email: mellytauliyandari@unib.ac.id

\section{Adif Jawadi Saputra. S.Pd., M.Pd., Kons.}

Guidance and Counseling Islam, Dakwah and Communication faculty

UIN Sumatera Utara

Jl. William Iskandar Ps. V, Medan Estate, Kec. Percut Sei Tuan

Kabupaten Deli Serdang, Sumatera Utara 20371

Email: adifjawadi@gmail.com 